\author{
LEVYK BOGDAN, \\ Regional Scientific-Educational center at Lviv Polytechnic National University (Lviv, Ukraine) \\ e-mail:levykbs@gmail.com,ORCID 0000-0001-5100-0834
}

SKORNIEWSKI MARIUSZ,

Catholic University of Lublin (Lublin, Poland)

e-mail:mskorn@o2.pl,.ORCID0000-0001-8307-3122

\title{
THE ARMENIANS OF LVIV IN THE SCIENTIFIC STUDIES, WRITTEN AND SACRAL RECORDS ${ }^{1}$
}

The results of historiographic research devoted to the Armenian diaspora in Lviv are highlighted in the issue. The necessity of such historiographic presentation was enhanced by the high number of historical sources where the Armenians of Lviv were mentioned or described, and their scientific interpretations. The main principles of author's classification were the credibility of historical sources and artefacts as well as the chronological order of the studies' emergence which could be related to the history of whole city and to the periods of the Armenian community's struggle for their rights and privileges. Among the official documents, determined the authentic nature the Armenian community in Lviv, were the tax registries, royal estates' descriptions, the Armenian judicial acts and a controversial document "The Document of 1062 of Duke Fedor Dmitrievich", according to which the Armenians were introduced to Lviv for establishing the settlement and the credibility of which had been debatable to the present day. A separate part of the work is devoted to the most prominent historiographical studies and historical essays of the Armenians in Lviv. The new archive materials were included into the scientific usage; in particular, the attention was drawn to the preserved Armenian manuscripts in ancient Armenian that had been stored at the scientific library of Ivan Franko National University of Lviv and needed digitalization and restoration. The scientific work of professor Ya. R. Dashkevych, who was one of the most prominent researchers of the issue "The Armenians in Ukraine" and other national and foreign historians, was briefly described. The conclusion was drawn regarding to the necessity of Ukrainian history's enrichment by the Armenian's issue.

Key words: The Armenians of Lviv in the scientific studies; the source classification; historical beliefs; Ya. Dashkevych; the Armenian manuscripts.

\section{Introduction}

Initiating a study of city's history and its population, a researcher has inevitably encountered the variety of ethnical communities and so called "the urban nations" each with a desire for legitimation its past through "a myth of foundation" (Assman, 2004). The older and more prominent is a myth, the higher is the kinship of ethnical community with the developed territory. Moreover a myth implies a true belief in the role of territory's influence on establishing a community and its history (Hobsbaum, 2001: 113).

The Armenians as other "urban nations" of Lviv obtained from the king of Poland Kazimierz III the confirmation of their rights to trial autonomy in 1356, which implied the authenticity of the Armenians in the city long before the Polish conquest of 1349. Nevertheless, during the following three centuries, having claimed their economic and civil rights and freedoms to the Lviv and Poland government, they had to prove constantly the inviolability and legitimacy of their rights based on the pragmatic evidences of their origins and legitimate proofs of being on the territory. The pragmatic artefacts are various types of supporting letters to ownership, historical narratives, and geographical and topographical descriptions of the territories. Owing to

\footnotetext{
1 The author expresses gratitude to Tihran Arutyunov for financing the presented publication.
}

the materialistic nature of evidences, they are the effective instruments of using and constructing the past, furthermore they become a subject of public and scientific discussions under particular political circumstances.

An issue of "the Armenians' origins" has constantly been an urgent subject of study from the $18^{\text {th }}$ century and nowadays it has not lost its relevance in the historical discourse of Ukraine and Poland. The fact has contributed to the appearance of wide variety of ancient written works, sources and their scientific interpretations, which historiographic descriptions and classification approaches need to be studied.

In the presented issue we are aimed at performing a scientific classification of sources and documents that are the base of the studies related to the Armenians of Lviv. We determined the credibility of historical sources and chronological order of studies' emergence as the cardinal principles of division, except the source and literature base separation and description of issue. Consequently, a pike of scientific interest to the Armenian history could be understood and particular parallels could be drawn between the whole city's history and the periods of the Armenian community's struggle for their rights, privileges or historical artefacts.

The first part of our study devoted to a description of historical sources which proved the Armenians' presence 
in Lviv. These were the official documents of Polish government related to a city's reception of Magdeburg right; later among them were the additional registers, descriptions of royal estates and Armenian's judicial acts. The second part of study discovered the discussions referred to "The document of 1062", that was a historical source proved the Armenians' appearance in Lviv, however which credibility was repeatedly doubtful by the government officials who were forced to prove or reject the legitimacy and authenticity of the Armenian community in Lviv in the $16^{\text {th }}-17^{\text {th }}$ centuries and by the later scientists of the $19^{\text {th }}$ $20^{\text {th }}$ centuries who considered "The document" to be a huge "falsification" and defended the thought with the compelling arguments.

The division of researchers of the Armenian community of Lviv according to the chronological principle (before 1914 and after the date, who studied the issue in the other decades of the $20^{\text {th }}$ century and in modern times) influenced on the $3^{\text {rd }}$ and $4^{\text {th }}$ part of research creation and permitted to demonstrate the context and social motivation affected the authors' scientific conclusions.

The methods were chosen according to the critical thinking analysis with the aim to generalize, to the extent possible, all informational complexes that were in the ancient sacral and written documents on Armenian history, in particular during the $11^{\text {th }}-17^{\text {th }}$ centuries, and the scientific studies of Russian, Polish and Ukrainian historians. The historical-genetic, historical-typological and descriptive methods were used in the study. The empirical information was obtained through the analysis of literature, archive sources and scientific journals.

\section{Results}

The discussion related to the credibility of a document, which contained the most ancient data of the Armenians' legitimization on the territory of Kyiv Rus, in particular on the lands of Lviv, was considered in the study. The reasons and development of the discussion which caused the researchers' division on two scientific opposing camps the adherents of critical approach and the supporters of apologetic approach, were defined. The new archive materials were included into the scientific usage; particularly the attention was paid to the Armenian's manuscripts in old Armenian which needed restoration and digitalization, preserved at the scientific library of Ivan Franko National University of Lviv. The scientific work of professor Ya. R. Dashkevych, who was one of the most prominent researchers of the issue "The Armenians in Ukraine" and other national and foreign historians, was briefly described. The conclusion was drawn regarding to the necessity of Ukrainian history's enrichment by the Armenian's issue.

\section{Discussions \\ Relating to the sources of Armenian's authenticity in Lviv}

The document of Lviv's reception of Magdeburg right in 1356 and permission of king of Poland Kazimierz III referred to the Armenian diocese organization centered in Lviv on February $4^{\text {th }} 1367$ should be considered the official documents determined the Armenians' presence in Lviv. The participants of round table "The Armenian Church in Ukraine from the Beginning to the Present Time" (which took place in Lviv during $21^{\text {th }}-23^{\text {rd }}$ of May 2018) came to that conclusion. According to the materials of discussions printed as a separate collection with a title "Religious and Cultural Life of the Armenian Diaspora in Ukraine from the Beginning to the Present Time. Dedicated to $650^{\text {th }}$ Anniversary of Lviv's Diocese of the Armenian Apostolic

ISSN 1728-9343 (Print)

ISSN 2411-3093 (Online)
Church" (2018), we were informed that king of Poland Kazimierz III gave permission for Armenian Bishop Gregory I to organize a residence in Lviv and conduct the religious services according to the existed customs and traditions in 1367. The document was in Lviv to 1944 until it was transported to Poland ${ }^{2}$.

Bishop Gregory I established a personal residence, having preserved the Armenian customs and language in a liturgy in Lviv on February $4^{\text {th }} 1367$. A king's diploma was in the archive of ancient acts of Lviv's city (in Lviv). In 1944 a document with other archive and library's treasures was transported deep into the territory of Poland. The document was selected for evacuation by Karol Badetskyi the head of archive of Lviv in January 1944. He selected 814 items of manuscripts on parchment dated 1234-1796. All the documents stored in Benedict abbey in Tyniec before a departure. After the war the document was not returned to Lviv and was directed to the Main Archive of State Acts in Warszawa (Matviyiv, 2001).

Cilician Katalikosice Theodoros II tried to replace Lviv's Bishop, Gregory I via defrocking him twice in 1383 and 1388 , and issuing the permission (kondak) to another candidate Govganess Nasretinian. In 1388 Lviv's Bishop applied to king's protection of W ładysław II Jagieł ło who confirmed the privileges given by Kazimierz III.

The first partial publishing of the mentioned document was performed by Polish historian Adam Naruszewicz in a multi-volume edition "The History of Polish Nation" in 1803 (Naruszewicz, 1803). The second editor of kondak was F. Zacharyasiewicz, the third was S. Baracz. The publication of Polish translation was performed by professional historian and editor Oleksandr Czolowski in Lviv in 1934.

Prior to Władysław Jagieł ło the confirmation of the Armenian rights was given by regent of the kingdom of Poland Elżbieta Łokietkówna (1305-1380) in 1379 and Ludwik Wegierski (1326-1382) in 1380. Furthermore, in 1462 king Kazimierz IV Jagiellończyk (1427-1492) approved all the rights of the Armenians and permitted them to leave the jurisdiction of government officials in Lviv. At that time Christin was an Armenian voigt. After the permissions released by Kazimierz IV Jagiellończyk, the following kings confirmed conventionally the rights of the Armenian community of Lviv. The famous confirmation of the Armenian rights in 1633 and 1641 was done by king of Poland Wtadyst aw IV (1595-1648) (Zacharyasiewicz, 1842: 20). The frequent confirmation of rights was a sign of constant struggle of the Armenians against Polish nobility in Lviv.

The crucial historical source which contained the information regarding to the propriety status and skills of the Armenians of Lviv was the tax registries, descriptions of royal estates. In particular the list of the Armenians, lived in Lviv's outskirt Pidzamche near a monastery of St. Anna, preserved (Hrushevskyy, 1900: 341-347).

The prominent source of internal community life of the Armenians of Lviv is the judicial acts. There are 7 books of Armenian municipal court related to the period of the $16^{\text {th }}$ century in the Central State Historical Archive in Lviv. There are the protocols of civil trials of 1537-1600-s and the protocols of Armenian commissions of jurors of 15781615-s among them. All the acts are in Latin, except some private letters in Armenian. The court books of 1559-1572$\mathrm{s}$ disappeared during the Second World War; they could be exported by the occupying authorities in spring 1943 .

\footnotetext{
2 The historical archive had a name of Bernard's archive as it was situated in Bernard's monastery at the time when Lviv was a part of Poland.
}

SKHID No. 4 (162) July-August 2019 
The so called "dyplomatary" - a collection of documents' copies referred to the obtained rights and privileges, reflected most comprehensively the legal rights (given or established) of the Armenian community in Lviv from 1356. Such collection was compiled by Armenian nobility of Lviv in $1595^{3}$.

The Armenian manuscripts can be found at the scientific library of Ivan Franko National University of Lviv and in Lviv Department of Central Historical Museum of Ukraine situated on the square Soborna. There are few studies related to the mentioned problematics in Lviv as well as in Ukraine. A compound catalogue of the Armenian manuscripts does not exist as well as there are no professionals of appropriate level. The ancient Armenian language grabar is a rare language in which only a few are competent. Nowadays, there are 11 of the Armenian manuscripts at the library's reserve collections. Before the Second World War in 1939 there were 23 items, 12 of them were transported on the territory of Poland by the German occupation authorities in $1943^{4}$

The best researchers of scientific direction remained Ya. R. Dashkevych and father Nerese Akinian and his work "The Main Catalogue of the Armenian Manuscripts at Lviv University Library of Lviv and Stanislaw Diocese", Viena 1961. The catalogue of Nerese Akinian included 23 Armenian manuscripts of 49 which were at the university library. Additionally father G. Meliksedekian described an unknown manuscript - a church songbook of 1785 .

The catalogue of the Armenian manuscripts was composed by Frederik Makler.

The Armenian manuscripts can be found at the reserve collections of the Imperial library in Vienna, including the manuscripts from Zamość town in Poland that were added to the collection after the decline of local community. A part of the manuscripts from Vienna were presented to the university in Lviv where history of the Armenian Church is studied at the theological department.

Nowadays, 11 of the Armenian manuscripts of Ivan Franko National University of Lviv are related to the church sphere. The manuscripts' condition is poor, they need restoration and digitalization. Nobody, except father Nerese Akinian worked with them till 1970. After 1970-s each manuscript had approximately three researchers. French scientist Klod Mutafian has studied the manuscripts for the last five years. Moreover the manuscripts were considered by Norain Pogosian, an associate professor at the Armenian Language Department of Yerevan University (Mesropyan, 2018).

\section{Relating to "The Document of 1062"}

An issue of the document of 1062 granted by Duke of Kyiv Rus Fedor Dmitrievich to the Armenians with an offer to settle on Rus was widely debated by Ukrainian, Polish, Armenian and Russian historians of the last century. The data is currently presented as a key point of the Armenians' appearance on the territory of modern Ukraine. The document in Latin translation was officially included into the Crown metric book in Warszawa on October $21^{\text {st }} 1641$ (Kapral, 2002). Ukrainian historian, professor, Lviv citizen Yaroslav Romanovich Dashkevych in his article "A document of Fedor Dmitrievich of 1062 (an essay of Ukrainian diplomacy)" (1962) and Armenian researcher

\footnotetext{
3 Рукописний відділ Львівської національної наукової бібліотеки ім. В. Стесраника АН України. [The manuscript Department of Stefanyk National Science Library of the National Academy of Sciences of Ukraine].

4 Газета Вільна Україна [Free Ukraine Newspaper]. 25.08.1944 р.
}

V.A. Mikaelian in the work "Referring to the issue of a document of Fedor Dmitrievich" (1965) tried to initiate a scientific polemic of the issue in 1960-s. A scientific community did not support a discussion, as a result the issue should be considered open till nowadays. Consequently, all opposing sides remained on their positions.

The Armenian community of Lviv, which defended their rights against Polish nobility, gave to king Władysław IV Waza some documents for the approval in 1641. This data was proved by historian and archivist Oleksandr Czolowski (1935). The Armenian documents guaranteed some economic and political privileges. There was a document of Fedor Dmitrievich of 1061 among the documents. The document's text was related to the duke's appeal to the Armenians of providing him the military aid for which three years of freedom were guaranteed. The crown office examined the document, translated it in Latin, and recognized it to be authentic. The Latin translation was registered in the crown office on November $17^{\text {th }} 1641$, an original was returned to the Armenian community in Lviv. The document's text in the modern interpretation is following: "From the grand Duke Fedor Dmitrievich to the Armenians of Kosograd who have the will to come here and will come for the assistance. For those who come I will give freedom for three years, and if they have a wish to stay under my authority, I will let them to settle on the land according to their desire" 5 .

Some historians consider a document to be a historical source of the $11^{\text {th }}$ century; others suppose it to be falsification. The document enhanced the status of the Armenians and identified their arrival at Kyiv Rus in the $11^{\text {th }}$ century in the light of warriors in lieu of refugees. The document was internationally recognized. Its text was consistently used during the law suits for proving the eternal rights of the Armenians on Ukrainian lands. One more time, the document appeared in the crown court as a convincing document in 1654. The document was also mentioned as a legal document during a law suit in 1731 (Baracz, 1869).

In 1809 I.Y. Simonovich, Armenian Archbishop of Lviv, used the document before Russian Emperor Oleksandr I as an evidence of Armenian nobility's origins on Ukrainian lands of the $11^{\text {th }}$ century. The fact was mentioned in the Polish Armenians life description of the $19^{\text {th }}$ century by Sadok Baracz, Galician Polish religious leader, historian, folklorist, archivist and an Armenian due to the origins (Baracz, 1865).

German traveler U. fon Verdum mentioned the document in Lviv in 1670.

Furthermore, French orientalist (occupied by the oriental studies) and religious leader L.M. Pidu de Sent-Olon remembered the document in 1680 .

The document of 1062 has widely used in the Armenian historiography from the $18^{\text {th }}$ century.

S. Roschkian (Roschka), a Ukrainian Armenian, linguist and historian mentioned the document of 1062 in his work "Life Description of the Armenian Bishops in Poland $\left(17^{\text {th }}\right.$ century)" for the first time among the Armenians.

Polish orientalist T. Krusinskyi performed an overview of the first Armenian colonies in Kyiv Rus based on the document of 1062 .

Moreover, the data 1062 entered into scientific literature and science fiction.

The Armenian researchers often applied to the docu-

\footnotetext{
5 Головний архів давніх актів у Варшаві. Коронна метрика. Книга записів. [The Central Archive of Historical Records in Warszawa. The Crown metrics. The Book of Registers] T. 187, арк. 139
} 
ment in the $19^{\text {th }}$ century. There is an Armenian translation of the document of 1062; however it is in a quite poor condition. It was published by Armenian historian and geographer Stepanos Guver Agonts (1802), who was followed by linguist Minas Bzischkian (1830), and Armenian historian, ethnographer and archeologist Gukas Inchichian (1835).

The document of 1062 was a subject of study by the Western Ukrainian Armenian historians F. K. Zacharyasiewicz (1842) and S. Baracz (1865; 1869). The last one is supposed to be the best expert of the Armenian past in Ukraine.

At the beginning of the $19^{\text {th }}$ century the document was analyzed by Ukrainian historians and linguists $D$. Michalskyi and I. Garbachevskyi, and later A. Petrushevich (1853), I. Lynnychenko (1899). All of them considered it to have the authentic nature.

T. Chatskyi, a Polish researcher was the first who doubted about the authentic nature of the document at the end of the $18^{\text {th }}$ century. He investigated the document's original personally, nevertheless his conclusions remained unpublished.

Ukrainian historian D. Zybrytskyi, an expert in medieval diplomacy was against the authentic nature of the document. A historian I. Scharanevich had a neutral position. In addition, a historian of the Armenian law application on Ukraine territory, an Austrian, F. Bischoff rejected to make his position public in 1864 .

The authentic nature of the document of 1062 was meticulously studied by Polish researcher T. Gromnitskyi at the end of the $19^{\text {th }}$ century. His conclusion was neutral. The position was shared by Polish historian O. Baltser. The historians came to a conclusion that the document could not be considered as an evident source of mass migration of the Armenians in Kyiv Rus in the $11^{\text {th }}$ century.

The Soviet Armenian historians accepted the data of 1062, for instance V. K. Voskanyan (1961).

Moreover the position was supported by Russian scientists S. Glinka (1833), and V. Urgevich, Polish historian U. Rolle, German historian K.F. Neiman, Romanian historian D. Dan, Hungarian historian Ch. Lukachi.

Lviv historian and researcher of the Armenian studies Yaroslav Dashkevich supported the same position regarding to non-acceptance of the authentic nature of the document. The essence of his position was the following: In 1062 the grand Duke Iziaslav Yaroslavovich was on the throne of Kyiv Rus. According to the German and Italian sources he was known as Dmitryi, however he did not have any son named Fedor. Consequently, the author of the document was not among the dukes of Kyiv (Dashkevych, 1962)

The attempts to identify personality of Duke Fedor Dmitrievich were unsuccessful. The data itself of 1062 was not put on the document, it was written into the document during the process of its registration by the crown office only in 1641 . The document did not have an author's signature and an addressee, for instance Armenian Duke. The enumerated facts revealed the inadmissibility of an international document design related to that time. Galician Armenian researcher Frantz Zacharyasiewicz offered to accept the data 1062 as the Armenian chronology which related to 1615 according to the European chronology, nevertheless, such proposition did not prove the authentic nature of the document.

There was the crown office where the chronology was performed; all the documents were stored in an archive in the Principality of Galicia-Volhynia. As a result, the appearance of the document which violated the accepted norms would draw public attention.
The document occurred unexpectedly in 1641. A reasonable question could be posed, why did the Armenian community not use it for the autonomy preservation in the kingdom of Poland and wait almost 600 years?

Polish nobility expressed negative attitude to the Armenians-Christians, considered them to be schismaticsecessionists and aimed at instilling the Polish and Catholic traditions to them. Consequently, the urban authorities of Polish Lviv endeavored to eliminate the Armenian's autonomy, their rights, national trial system, customs and traditions.

In the view of the abovementioned, professor Yaroslav Dashkevych drew a conclusion that the document of Duke Fedor Dmitrievich was falsification (Dashkevych, 1962).

The medieval documents were composed according to the established traditions in Europe. They had to contain the mandatory attributes: a title, approval, witnesses, and data.

In the $16^{\text {th }}$ century, particularly in 60-s, cardinal Jh. F. Kommendone, his secretary, historian A. M. Gratsiani, preacher B. Gerbest personally communicate with the Lviv Armenians in the matter of their appearance in Galicia. A question about the document of 1062 was not raised. Gerbest entailed a list of the documents and the Armenian manuscripts which he studied in Lviv in his work of 1567 . Still the document of 1062 was not mentioned.

The Soviet historiography was on the positions of rejecting the document's authentic nature; moreover there were attempts to exclude it completely from the scientific literature.

Relating to the Researchers of the Armenian Diaspora of Lviv before 1914

The first descriptions of the Armenians of Lviv appeared in the $16^{\text {th }}$ century. At that time the geographical and topographical descriptions of the Eastern Europe were in trend, including the description of the kingdom of Poland and the kingdom of Lithuania where the Ukrainian lands were included. The Armenian colonies were characterized by craft and trade nature. The one of the biggest Armenian community was situated in Lviv. Furthermore, the Armenian communities were in Kyiv, Lutsk, Yazlovets, KamenetsPodolskyi. The Armenian communities had partial economic and legal autonomy from local government. An Armenian court, where an Armenian voigt voted with the old men jurors, issued decisions according to the established traditions.

The first written note about the Armenians was created by Matsei from Mekhov, a reformer of Krakow university, in his book "A Treatise about Double Sarmatia: Asian and European ones" (1517). The author described the Armenians as an active nation which secured the trade and diplomatic mediation between the West and East (Mekhovskiy, 1936).

The second historian (according to the chronological order) who mentioned the Armenians of Lviv in writing was Italian geographer, corrector Giovanni Botero (1533-1617), who published 4 volumes of "The Reason of State", where in the first volume he depicted the territory of contemporary the kingdom of Poland (Mytsyk, 1982).

The $16^{\text {th }}$ century frightened the Catholic Church by the ideas of Reformation that had rapidly lost the positions in Europe, especially in German where Protestantism had been winning. Consequently, Vatican directed his emissaries, Apostolic Nuncios for studying and forecasting of the religious situation on a territory where potential converts lived. The Ukrainians were among them; however they were inclined to the Orthodox Church. It was completely true in the situation of the Armenian (Gregorian) Apostolic

SKHID No. 4 (162) July-August 2019 
Church that was one of the oldest as the nation was converted to the Christian belief back in the $4^{\text {th }}$ century.

Apostolic Ambassador (Nuncio) Giovanni Francesco Kommendone visited Lviv in 1564. His secretary Antony Maria Graziani in the biographical work "The Four Books about a Life of Cardinal Giovanni Francesco Kommendone", which issued in Paris in 1669, mentioned the Armenians of Lviv who had found a shelter in the city and where under the king's protection (Relacye nencyuszow apostolskich..., 1568).

Pope Nuncio Fulvio Ruggieri wrote about the high intellectual level of the Armenians of Lviv and their ancient manuscripts of 1565 and 1568 (see Vyrsky, 2012).

Furthermore, Polish statesman Szwientoslaw Ozelskyi (1549-1598) in "The Eight Books of Great Interregnum of 1572-1576" paid attention to the Armenian tradesmen form Lviv and their connections with Polish king SigismundAugustus (see Osypian, 2018).

Additionally, Archbishop of Lviv Yan-Dimitr Solikovskyi (1539-1603) in the book "A Short Commentary to Polish Problems" highlighted the economic might of the Armenians in 1579. The first publication was in Gdansk in 1647. Being a true defender of the Catholic Church and a religious union, Solikovskyi accused the Armenians of spying in favor of Turkey, being schismatics and supporting a religious division.

Polish Rzeczpospolita tried to attract the Armenians via enforcing the Polish and Catholic traditions. Later it had been accomplished through the signing of the union's statements with the Roman Catholic Church in 1654. Meticulous and systematic work of the Catholics was preceded by the event. For instance, canonic Andrzej Lubelczik wrote "A Liturgy of the Armenian Ceremony" in 1549, and issued a book "Baptism of the Armenians" in Krakow in 1554. He appealed for the common Armenian Catholic Church in his works.

Undeniably, the historical documents of the Armenian community in Lviv were the ample evidence of Armenian's incorporation into medieval city. "A Statute of the Armenian Law" of 1519 should be named among them. It was a base for the legal procedures in the Armenian local courts. The statute was published in seven textual variants in Armenian-Kipchak language, Latin and Polish ${ }^{6}$.

The historical documental collection of the Armenian colony in Lviv, published by Austrian historian of law F. Bischoff in Vienna in 1865, included more than 30 documents dated from the $16^{\text {th }}$ century which reflected a persistent struggle of the Armenians for their own administrative and legal autonomy against the application of Magdeburg right during the trials. There were the king's documents which gave the privileges to the particular Armenians in Lviv, for instance to Ivashkov Tichnovich - father and son, to Vasil son of Ivashko. The individual privileges were a reward for successfully performed diplomatic work, typically for the king's mail delivery or accompaniment of a diplomatic mission. Trading with Turkey, Iran, the Armenians were fluent in the foreign languages and personally knew the rulers, their court, as a result they had an opportunity of being the mediators in the international relations. The fact facilitated some representatives of the Armenian ethos to gain the trust of kings, sultans, viziers as well as to earn the fortune. The richest were the creditors of the kingdom of Poland on the security of the guaranteed letters from a king.

\footnotetext{
6 The Armenian local court was liquidated by the AustrianHungarian authorities in Lviv in 1784. Simultaneously, 6 Armenian parishes were eliminated, in which 9 churches and 19 chapels in three dioceses of Lviv, Stanislav and Kuty were included.
}

Vatican was regularly informed about the religious situation in Lviv by I.A. Kaligaria, I.A. Bolonetto, Pope Nuncios in Poland. The priests of the Armenian and Ukrainian Church were collectively against the introduction of Polish and Catholic traditions at the local level.

The Ukrainian Armenians communicate in ArmenianKipchak, it is a spoken language. Some researchers consider them to be the Polish Armenians, highlighting a differentiation in the political sphere.

A researcher should have paleographical skills (paleography - is a historical and linguistic discipline which studies the evolution of writing), be an expert in ancient Ukrainian, ancient and middle Armenian, Armenian-Kipchak, ancient Polish and Latin languages in order to provide a qualitative study of the period (Dashkevych, 1961).

The attempts to describe the Armenian community in Lviv were made by Polish historian D. Zubrzycki (1844).

Oswald Marian Balzer (1858 - 1933) ${ }^{7}$ should be named among the Polish researchers of the Armenian community and its legal documents in medieval Lviv (in the $5^{\text {th }}-16^{\text {th }}$ centuries). He maintained the position that the Armenians had their national voigt and the judicial procedures (namely the right to set a trial and to consider the legal suits) during the kings' times. There are no any additional documents due to the considered issue (Balzer, 1909).

Relating to the Researchers of the Armenian Diaspora of Lviv in the $20^{\text {th }}-21^{\text {st }}$ Centuries

A history of the Armenian settlements mentioned in "The Minor Chronicles of the $13^{\text {th }}-18^{\text {th }}$ centuries", composed during 1951-1956-s by researcher of Institute of History National Academy of Sciences of the Soviet Republic of Armenia V.A. Akopân (Akopân, 1951-1956)

Yaroslav Romanovich Dashkevych should be considered as the most distinguished Ukrainian scientistArmenolog. He studied the issue approximately 40 years. He presented his PhD thesis of Doctor of Philosophy in Yerevan in 1963 (Dashkevich, 1962). There were many pages devoted to the Armenians of Lviv in his monography of Doctor of Science "A State and Directions of resource and historical studies of Ukrainian History (the second half of the $19^{\text {th }}-20^{\text {th }}$ century)" (1994).

The Soviet authorities and its representatives did not give Ya. Dashkevych, a former repressed man (19491956), any opportunity to obtain a scientific degree in Ukraine. Armenian revolutionary and Soviet politician, historian, academic of National Academy of Sciences of the Soviet Republic of Armenia Ashot Govganisian (loanisian) facilitated him. He was also a victim of the Stalinist terror as Yaroslav Dashkevych and was rehabilitated in 1954. Professor Ashot Govganisian was an academic adviser of the $\mathrm{PhD}$ thesis of aspirant Yaroslav Dashkevych as well as he agreed to be a senior editor of his monography.

Nevertheless, a scientific career of Dashkevych on the Soviet Union territory was tough even after PhD degree approval. He was constantly dismissed, moreover he was not permitted to teach, write or be published. In 1972

\footnotetext{
7 Oswald Balzer graduated from the University of Lviv and JagielIonian university, law department. He got his $\mathrm{PhD}$ according to the thesis "The Genesis of the Kingdom of Poland" in 1883. He was an ordinary professor at the law department of the University of Lviv from 1887 to 1933 . In 1891 he occupied a position of a local archive's head of municipal law acts. He was an author of the prominent scientific studies of the Armenians' law documents in medieval Poland. He was nominated for the Noble Piece Prize in 1926. Buried in Lychakiv cemetery-museum in Lviv.
} 
professor Dashkevych was entered into a list of scientists who were prohibited from publishing the historical studies in the Soviet Union. Only in 1981 his works were issued in the Soviet Republic of Ukraine. Having the invitation from American professor, director of Ukrainian research institute, former Lviv citizen Omelian Pritsak to Harvard University for teaching, Yaroslav Dashkevych was banned from leaving the Soviet Union territory. A researcher had been under the supervision of the KGB till 1990.

The numerous works of professor Dashkevych devoted to the Armenians in Ukraine can be read in the collection of 2001 (Dashkevich, 2001). There are more than 120 scientific articles of different years in French and English among them.

Moreover, Ivan Kripyakevich (1963) studied the issue of genesis of the Armenian community in Lviv.

Professor of the Jagiellonian university (Krakow) Krzysztof Stopka occupied a prominent place among the Polish researchers. He published a detailed article related to the Armenian Church in Kyiv Rus in 1984 (Stopka, 1984) and issued a scientific article regarding to the document of 1367 (about the privileges of Armenian Bishop) and his meaning to the Armenians of Lviv in the Armenian Newsletter of Cultural Community in Krakow in 2017 (Stopka, 2017).

Miron Mykolaevich Kapral, an apprentice and follower of Yaroslav Dashkevych, professor of Lviv State University, head of Lviv Department of Ukrainian Institute of Archeology and Source Studies can be identified among the modern Lviv researchers of the Armenian community (Kapral, 2003; 2018).

Oleksandr Garkavets published the remarkable and extensive studies in his source materials collection "Kipchak Written Heritage" in 2002 (Garkavets, 2002: 7-8).

The Armenian issue is studied by the modern Lviv, Ukrainian and foreign historians, namely by Doctor of Philosophy, Associate Professor, Head of the Department of Handwritten, Old Printed and Rare Books of F.P. Maksimenko Scientific Library at Ivan Franko National University of Lviv Mykola llkiv-Svydnytskyi (2018), Doctor of Philosophy, Associate Professor Irina Gajuk (2018), Doctor of Philosophy, Associate Professor Oleksandr Osipian (2018), Head of Religion and National Department the Office for Nationalities, Religions and Financial Work of the Department on Culture, Nation and Religion of Lviv Local State Administration Taras Grynchyschyn (2018), member of the National Writers' Union of Ukraine, bibliographer of the first category of the Manuscript Department of Scientific Library at Ivan Franko National University of Lviv, translator, literary critic Anuschavan Mesropian (2018), Doctor of Science, Head of Philosophy and Economic Studies Department at Lviv National Medical University Igor Derzko (2018), Doctor of Philosophy, Associate Professor, Head of Law Department at Poltava V.G. Korolenko National Pedagogical University Karina Pivovarska, and Valdemar Deluga professor-habitat, doctor at University of Ostrava, Czech Republic.

\section{Conclusions}

A history of the Armenian diaspora on Ukrainian land occupies the prominent place in the urban communities' study. The resourceful and literature analysis of the issue permitted to organize and describe the available studies as well as to deep the knowledge related to the periods and methods of struggle of the Armenian community for their rights and privileges in medieval Lviv. Moreover, the presented study revealed the level of issue's urgency and discussion regarding to the exact date determination of the Armenians appearance on the Kyiv Rus territory.

ISSN 1728-9343 (Print)

ISSN 2411-3093 (Online)
The scientific essays of Polish, Russian and Ukrainian researchers of the issue are presented. Particularly, the scientific contribution on the subject of "the Armenian issue in Lviv" of Yaroslav Dashkevych, a historian with tough life and scientific destiny who has still remained the most recognized scientist of the Armenian studies in Ukraine, is described.

The attention is drawn to the necessity of further study and manuscripts' preservation in ancient Armenian which have been stored at the scientific library of Ivan Franko National University of Lviv and need digitalization and restoration.

\section{REFERENCES}

Akopân, V. A. (comp.) (1951-1956). Melkie hroniki XIIIXVIII vv. Erevan: izd. AN Armânskoj SSR, 1951-1956 (In Armenian)

Assman, J. (2004). Kulturnaya pamyat: pismo, pamyat o proshlom i politicheskaya identichnost $v$ vysokikh kulturakh drevnosti (Translate). Moscow: Yazyki slavyanskoy kultury. (In Russian)

Balzer, O. (1909). Sadownictwo ormianskie w sredniowiecznym Lwowie. Studya nad historya prawa polskiego. Lwów, Vol. IV. Z. 1. S. 9. (In Polish)

Baracz, S. (1865). Zywoty slawnych Ormian w Polsce. Lwow, 87. (In Polish)

Baracz, S. (1869). Rys dziejow ormianskich. Tarnopol, 61. (In Polish)

Czolowski, A. (1935). Cenny zabytek. Gregjriana, 1935. Vol. I, 12. (In Polish)

Dashkevich, Ya. (1962). Armyanskiye kolonii na Ukraine $v$ istochnikakh i literature XV-XIX vekov (Istoriograficheskiy ocherk). Yerevan, 1962. (In Russian)

Dashkevich, Ya. (2001). Virmeny i Ukrayina. Lviv-Nyu-York: Vydavnytstvo M. P. Kots. 760 p. (In Ukrainian)

Dashkevych, Ya. (1961). Dzherela i literatura pro virmenski koloniyi na Ukrayini $\vee 16$ st. Naukovo-informatsiynyy byuleten Arkhivnoho upravlinnya URSR. 6: 70-79. (In Ukrainian)

Dashkevych, Ya. R. (1962). Hramota Fedora Dmytrovycha 1062 r. (narys z ukrayinskoyi dyplomatyky). Naukovo-informatsiynyy biuleten Arkhivnoho upravlinnya URSR. 4, 9-19. (In Ukrainian)

Derzhko, I. (2018). Shchodo osoblyvostey virmenskoyi filosofsko-relihiynoyi dumky. Lvivskyy pohlyad. In: Relihiynokulturne zhyttya virmenskoyi diaspory $v$ Ukrayini vid yiyi pochatkiv do sohodennya. S. 146-161. Materialy kruhloho stolu "Virmenska tserkva v Ukrayini vid yiyi pochatkiv do siohodennya", 21-23 travnya 2018 r. Lviv: Lohos. (In Ukrainian).

Garkavets, Aleksandr. (2002). Kypchakskoye pismennoye naslediye. Tom 1. Katalog i teksty pamyatnikov armyanskim pismom. Alma-Aty, pp. 7-8. (In Russian)

Glinka, S. (1833). Obozreniye istorii armyanskogo naroda ot nachala bytiya yego do vozrozhdeniya oblasti armyanskoy $v$ Rossiyskoy imperii (Part 2), s. 232. (In Russian).

Hayuk, I. (2018). Deyaki problemni pytannya stosovno pochatkiv virmenskoyi tserkovnoyi orhanizatsiyi v Ukrayini. In: Relihiyno-kulturne zhyttya virmenskoyi diaspory v Ukrayini vid yiyi pochatkiv do sohodennya. S. 29-60. Materialy kruhloho stolu "Virmenska tserkva v Ukrayini vid yiyi pochatkiv do siohodennya", 21-23 travnya 2018 r. Lviv: Lohos. (In Ukrainian).

Hobsbaum, E. (2001). Vik ekstremizmu. Korotka istoriya XX viku, 1914-1991. Kyiv: Vydavnychyy dim Alternatyvy. (In Ukrainian)

Hrushevskyy, M. (1900). Opysy korolivshchyn v ruskykh zemlyakh 16 viku. Lyustratsyyi zemel Kholmskoyi, Belzkoyi i Lvivskoyi. In: Zherela do istoriyi Ukrayiny-Rusy, Vol. 3, Lviv, 341-347.

Hrynchyshyn, T. (2018). Virmenski khramy Lvova: heohrafiya ta khronolohiya. In: Relihiyno-kulturne zhyttya virmenskoyi diaspory v Ukrayini vid yiyi pochatkiv do sohodennya. S. 88-120. Materialy kruhloho stolu "Virmenska tserkva $v$ Ukrayini vid yiyi pochatkiv do siohodennya", 21-23 travnya 2018 r. Lviv: Lohos. (In Ukrainian)

Ilkiv-Svydnytskyy, M. (2018). "Kazymyrivski pryviley" virmenskomu yepyskopu Hryhoriyu 1367 r.: istoriya pobutuvannya i

SKHID No. 4 (162) July-August 2019 
doslidzhennya. In: Relihiyno-kulturne zhyttya virmenskoyi diaspory v Ukrayini vid yiyi pochatkiv do sohodennya. S. 3-28. Materialy kruhloho stolu "Virmenska tserkva v Ukrayini vid yiyi pochatkiv do siohodennya", 21-23 travnya 2018 r. Lviv: Lohos. (In Ukrainian).

Kapral, M. (2018). Upokiy dushi po-virmensky: zapovit Ivivskoho kuptsya Vartika $1460 \mathrm{r}$. In: Relihiyno-kulturne zhyttya virmenskoyi diaspory v Ukrayini vid yiyi pochatkiv do sohodennya. S. 61-73. Materialy kruhloho stolu "Virmenska tserkva v Ukrayini vid yiyi pochatkiv do siohodennya", 21-23 travnya 2018 r. Lviv: Lohos. (In Ukrainian).

Kapral, Myron (2002). Pravovyy ustriy virmenskoyi hromady Lvova XIV-XVIII st. Ukrayina $v$ Tsentralno-Skhidniy Yevropi (z naydavnishykh chasiv do XVIII st.). Kyiv. Issue 2, 136-150. (In Ukrainian)

Kapral, Myron (2003). Natsionalni hromady Lvova XVI-XVIII st. (sotsialno-pravovi vzayemyny). Lviv: LNU im. I. Franka, Lvivske viddilennya In-tu ukrayinskoyi arkheohrafiyi ta dzhereloznavstva im. M. S. Hrushevskoho NAN Ukrayiny. (In Ukrainian)

Kripyakevich, I. (1963). K voprosu o nachale armyanskoy kolonii vo Lvove. Istoriko-filologicheskiy zhurnal, 1: 163-165. (In Russian)

Lynnychenko, I. (1899). Suspilni verstvy Halytskoyi Rusi XIV - XV v. Lviv, s. 229 (In Ukrainian).

Matviyiv, M. (2001). Evakuatsiya polskykh zibran zi Lvova v 1944 r. Arkhivy Ukrayiny, 4-5: 149-163. (In Ukrainian).

Mekhovskiy, Matvey (1936). Traktat o dvukh Sarmatiyakh. Moscow-Leningrad: Izdayelstvo AN SSSR, S. 174-175. Retrieved from http://history-fiction.ru/get-book-file.php?id=5201

Mesropyan, A. (2018). Virmenski rukopysy $v$ kolektsiyi naukovoyi biblioteky Lvivskoho natsionalnoho universytetu imeni Ivana Franka (istoriohrafichnyy ohlyad). In: Relihiyno-kulturne zhyttya virmenskoyi diaspory $v$ Ukrayini vid yiyi pochatkiv do sohodennya. S. 120-128. Materialy kruhloho stolu "Virmenska tserkva $\vee$ Ukrayini vid yiyi pochatkiv do siohodennya", 21-23 travnya 2018 r. Lviv: Lohos. (In Ukrainian).

Mikayelyan, V. A. (1965). K voprosu o gramote knyazya Fedora Dmitriyevicha. Arkheograficheskiy yezhegodnik za 1964 god (Moscow), 11-18. (In Russian)

Mytsyk, Yu. A. (1982). Istoryko-heohrafichnyy opys Ukrayiny u tvori italiyskoho humanista XVI st. Dzhovanni Botero. Istorychni doslidzhennya. (Vitchyznyana istoriya), 8. 29-33 (In Ukrainian)

Naruszewicz, A. (1803). Historia Narodu Polskego, od poczatku chrestianstwa. Warszawa, 1803. T. 6: Panawanie Hiastrow, s. 186-187. (In Polish)

Osipian, O. (2018). Korysni poputnyky zi Lvova do Stambulu: virmenski kuptsi ta polski posolstva u 16-17 st. S. 74-87. Relihiynokulturne zhyttya virmenskoyi diaspory $v$ Ukrayini vid yiyi pochatkiv do siohodennya. Do 650-richchya Lvivskoyi yeparkhiyi Virmenskoyi Apostolskoyi tserkvy. Materialy kruhloho stolu, 2123 travnya 2018 r., Lviv. (In Ukrainian)

Petrushevich, A. (1853). Obzor vazhneyshikh politicheskikh i tserkovnykh proisshestviy $\mathrm{v}$ galitskom knyazhestve s poloviny XII do kontsa XIII v. Zorya galitskaya, № 37, s. 420-422 (In Russian)

Relacye nencyuszow apostolskich s innych osob o Pollsce od roku 1548 do 1690 (1864). Tom I. Berlin-Poznan. Retrieved from https://books. google.ru/books? id=JmIKAAAAcAAJ\&pg=PA165\&hl=ru\&source $=g b s \_t o c \_r \& c a d=3 \# v=o n e p a g e \& q \& f=f a l s e$. (Accessed 17.06.2019).

Stopka, Krzysztof. (1984). Kosciol ormianski na Rusi w wekach srednich. Nasza przeszlosc, 62: 27-95 (In Polish).

Stopka, Krzysztof. (2017). Okolicznosci i znaczenie dokumentu z 1367 roku. Biuletyn Ormianskego Towarzystwa Kulturalnego. Nr. 88/89. s. 3-8. (In Polish).

Voskanyan, V. K. (1961). Drevnyaya Rus i Ukraina v sudbakh armyan. In: Istoricheskiye svyazi i druzhba ukrainskikh $i$ armyanskikh narodov, Yerevan, s. 63-64 (In Russian).

Vyrsky, D. (2012). Richpospolytska istoriohrafiya Ukrayiny (kinets XV st. - 1659 r.) pp. 27-150. In: O. A. Udod (vidp. red. ta kerivnyk avt. kol.) Akademichni y doakademichni obrazy ukrayinskoyi istoriohrafiyi. Kyiv: NAN Ukrayiny. In-t istoriyi Ukrayiny (In Ukrainian).
Zacharyasiewicz, F. X. (1842). Wiadomosc o Ormianach w Polsce. Lwow, s.10 (In Polish).

Zubrzycki, D. (1844). Kronika miasta Lwowa. Lwow, s. 55. (In Polish)

\section{LIST OF REFERENCE LINKS}

Ассман Ян. Культурная память: письмо, память о прошлом и политическая идентичность в высоких культурах древности ; пер. с нем. Москва: Языки славянской культуры, 2004. 368 с

Вирський Д. Роксолани серед Сарматів: Річ Посполитська історіографія України (кінець XV ст. - 1659). Київ: Інститут історії України НАН України, 2013. 295 с.

Гаркавец Александр. Кыпчакское письменное наследие. Том 1. Каталог и тексты памятников армянским письмом. Алма-Аты, 2002. С. 7-8.

Гаюк І. Деякі проблемні питання стосовно початків вірменської церковної організації в Україні. Релігійно-культурне життя вірменської діаспори в Україні від їі початків до сьогодення. До 650-річчя львівської єпархії Вірменської Апостольської церкви: матеріали круглого столу "Вірменська церква в Україні від її початків до сьогодення", 21-23 травня 2018 р., Львів: Логос, 2018. С. 29-61.

Глинка С. Обозрение истории армянского народа от начала бытия его до возрождения Области армянской в Российской империи, ч. 2. Москва, 1833. С. 232.

Гобсбаум Е. Вік екстремізму. Коротка історія XX віку 19141991. Київ: ВД "Альтерантиви", 2001.

Гринчишин Т. Вірменські храми Львова: географія та хронологія. Релігійно-культурне життя вірменської діаспори в Україні від їі початків до сьогодення. До 650-річчя львівської єпархії Вірменської Апостольської церкви: матеріали круглого столу "Вірменська церква в Україні від її початків до сьогодення", 21-23 травня 2018 р., Львів: Логос, 2018. С. 88-120.

Грушевський М. Описи королівщин в руських землях 16 віку. Люстрациї земель Холмської, Белзької і Львівської / Жерела до історії України-Руси, Т. 3, Львів, 1900. С. 341-347.

Дашкевич Я. Армянские колонии на Украине в источниках и литературе 15-19 вв. (Историографический очерк). Ереван, 1962.

Дашкевич Я. Р. Грамота Федора Дмитровича 1062 р. (нарис з української дипломатики). Науково-інформаційний бюлетень Архівного управління УРСР. 1962. № 4. С. 9 -19.

Дашкевич Ярослав. Вірмени і Україна. Львів-Нью-Йорк: Видавництво М. П. Коць, 2001. 760 с.

Дашкевич Ярослав. Джерела і література про вірменські колонії на Україні в 16 ст. Науково-інформаційний бюлетень Архівного управління УРСР. 1961. № 6. С. 70-79.

Держко І. Щодо особливостей вірменської фрілософськорелігійної думки. Львівський погляд. Філософський ессей. Релігійно-культурне життя вірменської діаспори в Україні від їі початків до сьогодення. До 650-річчя львівської єпархії Вірменської Апостольської церкви: матеріали круглого столу "Вірменська церква в Україні від її початків до сьогодення", 21-23 травня 2018 р., Львів: Логос, 2018. С.146-162.

Ільків-Свидницький. "Казимирівські привілей" вірменському єпископу Григорію 1367 р.: історія побутування і дослідження. Релігійно-культурне життя вірменської діаспори в Україні від ії початків до сьогодення. До 650-річчя львівської єпархії Вірменської Апостольської иеркви: матеріали круглого столу "Вірменська церква в Україні від ії початків до сьогодення", 21-23 травня 2018 р., Львів: Логос, 2018. С. 3-28.

Капраль М. Упокій душі по-вірменськи: заповіт львівського купця Вартіка 1460 р. Релігійно-культурне життя вірменської діаспори в Україні від ії початків до сьогодення. До 650річчя львівської єпархії Вірменської Апостольської церкви: матеріали круглого столу "Вірменська церква в Україні від її початків до сьогодення", 21-23 травня 2018 р., Львів: Логос, 2018. С. 61-73.

Капраль Мирон. Національні громади Львова 16-18 ст. (соціально-правові взаємини). Львів, 2003. С. 40.

Капраль Мирон. Правовое устройство армянской общины Львова в XIV-XVIII веках. Обзор документов. URL: http:// 
www.qypchaq.freenet.kz/Docs/Code-Law/Qypchaq-Laws-741754.pdf. (дата звернення: 29.05.2019).

Крипьякевич И. К вопросу о начале армянской колонии во Львове. Историко-филологический журнал. 1963. № 1. С. $163-165$

Линниченко І. Суспільні верстви Галицької Русі XIV - XV в. Львів, 1899. С. 229.

Матвіїв М. Евакуація польських зібрань зі Львова в 1944 р. Архіви України. 2001. № 4-5. С. 149-163.

Мелкие хроники 13-18 вв. / Акопян В. А. (упор.). Тт.1-2. Ереван: Изд. АН Армянской ССР, 1951-56 (арм.яз.).

Месропян Анушаван. Вірменські рукописи в колекції наукової бібліотеки Львівського національного університету імені Івана Франка (історіографічний огляд). Релігійно-культурне життя вірменської діаспори в Україні від їі початків до сьогодення. До 650-річчя львівської єпархії Вірменської Апостольської церкви: матеріали круглого столу "Вірменська церква в Україні від її початків до сьогодення", 21-23 травня 2018 р., Львів: Логос, 2018. С. 121-128.

Меховский Матвей. Трактат о двух Сарматиях. МоскваЛенинград, 1936. С. 174-175.

Микаелян В. А. К вопросу о грамоте князя Федора Дмитриевича. Археографический ежегодник за 1964 год. Москва, 1965. С. 11-18.

Мицик Ю. А. Історико-географічний опис України у творі італійського гуманіста XVI ст. Джованні Ботеро. Історичні дослідження. Вітчизняна історія. 1982. вип. 8.

Петрушевич А. Обзор важнейших политических и церковных происшествий в галицком княжестве с половины XII до конца XIII в. "Зоря галицкая". Львов, 1853. № 37. С. 420-422.
Осіпян О. Корисні попутники зі Львова до Стамбулу: вірменські купці та польські посольства у 16-17 ст. Релігійнокультурне життя вірменської діаспори в Україні від їі початків до сьогодення. До 650-річчя львівської єпархії Вірменської Апостольської церкви: матеріали круглого столу "Вірменська церква в Україні від її початків до сьогодення", 21-23 травня 2018 р., Львів: Логос, 2018. С. 74-87.

Balzer O. Sadownictwo ormianskie w sredniowiecznym Lwowie / Studya nad historya prawa polskiego. Lwów, 1909. T. IV. Z. 1. S. 9 .

Czolowski A. Cenny zabytek. Gregjriana, 1935. T. I, s. 12.

Naruszewicz A. Historia Narodu Polskego, od poczatku chrestianstwa. Warszawa, 1803. T. 6: Panawanie Hiastrow, s. $186-187$.

Relacye nencyuszow apostolskich s innych osob o Pollsce od roku 1548 do 1690. Tom I. Berlin-Poznan 1864. URL: https:// books.google.ru/books? id=JmIKAAAAcAAJ\&pg=PA165\&hl=ru\&source $=g b s \_t o c \_r \& c a d=3 \# v=o n e p a g e \& q \& f=f a l s e$. (дата звернення 20.06.2019).

Baracz S. Rys dziejow ormianskich. Tarnopol, 1869. s. 61.

Baracz S. Zywoty slawnych Ormian w Polsce. Lwow, 1865. s. 87.

Stopka Krzysztof. Kosciol ormianski na Rusi w wekach srednich. Nasza przeszlosc, 1984. T. 62. S. 27-95.

Stopka Krzysztof. Okolicznosci i znaczenie dokumentu z 1367 roku. Biuletyn Ormianskego Towarzystwa Kulturalnego. Krakow, 2017. Nr. 88/89. s. 3-8.

Zacharyasiewicz F. Wiadomosc o Ormianach w Polszcze. Lwow, 1842. s. 20.

Zubrzycki D. Kronika miasta Lwowa. Lwow, 1844. s. 55.

Левик Богдан,

Регіональний науково-навчальний центр

Національного університету "Львівська політехніка" (м. Львів, Украӥна)

e-mail:levykbs@gmail.com,ORCID 0000-0001-5100-0834

Скорнсвський Маріуш,

Люблінський католищький університет (м. Люблін, Польща)

e-mail: mskorn@o2.pl, ORCID0000-0001-8307-3122

\section{ВІРМЕНИ ЛЬВОВА У НАУКОВИХ ДОСЛІДЖЕННЯХ, ПИСЕМНИХ ТА САКРАЛЬНИХ ПАМ'ЯТКАХ}

У статті висвітлено результати історіографічного дослідження, присвяченого вірменській діаспорі Львова. Необхідність такого історіографічного упорядкування зумовлена величезною кількістю історичних джерел, у яких згадуються чи описуються львівські вірмени, та їх наукових інтерпретацій. Принципами авторської класифікації є достовірність історичного джерела, а також хронологічний порядок появи наукових досліджень, які можна співвіднести 3 історією цілого міста та періодами боротьби вірменської громади за свої права, привілеї чи історичні артефакти. Серед офіційних документів, які вказують на автентичність вірменської громади Львова, податкові реєстри, описи королівських маєтків, вірменські судові акти, а також досить суперечливий документ "Грамота 1062 р. князя Федора Дмитровича", якою вірмени були запрошені до Львова на поселення і достовірність якої до сьогодні дискутується. Окремий розділ роботи - розгляд найбільш значних історіографічних досліджень та доробку окремих дослідників історії львівських вірмен. У результаті дослідження уведено до наукового обігу нові архівні матеріали, зокрема звернуто увагу на збережені вірменські рукописи давньовірменською мовою, які зберігаються в науковій бібліотеці Львівського університету імені Івана Франка і потребують оцифрування та реставрації; коротко охарактеризовано науковий доробок професора Я. Р. Дашкевича, як одного з найбільш знаних дослідників проблематики "вірмени в Україні" та інших вітчизняних і зарубіжних істориків. Зроблено висновок про необхідність доповнити історію України вірменською проблематикою.

Ключові слова: Вірмени Львова у наукових дослідженнях; класифрікація джерел; історичні уявлення; Я. Дашкевич; вірменські рукописи.

(C) Levyk Bogdan, Skorniewski Mariusz

Надійшла до редакції: 28.06.2019

Прийнята до друку: 23.07.2019 